\title{
KRÓTKIE ODSTĘPY CZASU JAKO WARUNEK CZYNU CIĄGEEGO
}

Czyn ciagły został uregulowany w art. $12 \S 1$ ustawy z 6 czerwca 1997 r. Kodeks karny w następujący sposób: „Dwa lub więcej zachowań podjętych w krótkich odstępach czasu w wykonaniu z góry powziętego zamiaru uważa się za jeden czyn zabroniony; jeżeli przedmiotem zamachu jest dobro osobiste, warunkiem uznania wielości zachowań za jeden czyn zabroniony jest tożsamość pokrzywdzonego". Ustawą z 4 października 2018 r. o zmianie ustawy Kodeks wykroczeń oraz niektórych innych ustaw do art. 12 k.k. dodany został $\S 2$, którego brzmienie jest następujące: „Odpowiada jak za jeden czyn zabroniony wyczerpujący znamiona przestępstwa ten, kto w krótkich odstępach czasu, przy wykorzystaniu tej samej albo takiej samej sposobności lub w podobny sposób popełnia dwa lub więcej umyślnych wykroczeń przeciwko mieniu, jeżeli łączna wartość mienia uzasadnia odpowiedzialność za przestępstwo". Przepis ten wszedł w życie 15 listopada 2018 r.

Z przepisu art. 12 k.k. wynika, że z czynem ciagłym mamy do czynienia jedynie w razie koniunkcyjnego spełnienia następujących przesłanek: podjęcie przez sprawcę dwóch lub więcej zachowań, podjęcie tychże zachowań w krótkich odstępach czasu, podjęcie ich w wykonaniu z góry powziętego zamiaru, a nadto w przypadku zachowań, które uderzają w dobro osobiste, spełniony musi zostać warunek tożsamości pokrzywdzonego.

Sąd Apelacyjny w Katowicach w wyroku z 25 lutego 2010 r. zwrócił uwagę na to, że instytucja czynu ciagłego jest sztuczną konstrukcją prawna, co oznacza, że czyn ciagły istnieje w przestrzeni prawnej tylko o tyle, o ile sąd przyjmie w swym orzeczeniu, że zachodza przesłanki określone w art. 12 k.k. O skutkach procesowych popełnienia czynu ciagłego może być zatem mowa dopiero wówczas, gdy jego popełnienie zostanie przez sąd stwierdzone. Należy mieć jednak na uwadze to, że instytucja czynu ciagłego jest instytucją obligatoryjna, co oznacza, że jeżeli sąd ustali, że na gruncie konkretnego stanu faktycznego zachodza przesłanki do zastosowania tej instytucji, to konieczne jest przypisanie sprawcy czynu ciagłego - brak zatem jakiejkolwiek fakultatywności w tym zakresie ${ }^{1}$. Zwrócił na to uwagę Sąd Najwyższy m.in. w wyroku z 6 grudnia 2016 r., stwierdzając, iż sąd ma obowiązek zastosowania art. 12 k.k., jednakże obowiązek ten aktualizuje się dla niego dopiero wtedy, gdy po-

${ }^{1}$ II AKa 350/09, Lex nr 603272. 
czynione przez niego ustalenia faktyczne pozwalają na potraktowanie kolejnych zachowań, których dopuścił się sprawca, właśnie jako czynu ciagłego ${ }^{2}$.

Jak już na wstępie wspomniano, jedną z przesłanek umożliwiających przyjęcie czynu ciagłego są tzw. krótkie odstępy czasu. Zarówno w orzecznictwie, jak i w doktrynie nie ma jednak jednolitego poglądu na to, jaki maksymalny okres można traktować jako krótki odstęp czasu ${ }^{3}$. Z uwagi na to, że ustawodawca nie zamieścił w Kodeksie karnym definicji legalnej terminu „krótkie odstępy czasu", wyrażenie to sprawia zarówno doktrynie prawa karnego, jak i orzecznictwu sądowemu liczne trudności interpretacyjne.

Piotr Kardas stoi jednak na stanowisku, że pewne wskazania interpretacyjne dotyczące rozumienia pojęcia „w krótkich odstępach czasu” można wywieść już z samego kontekstu, w jakim umieszczone zostało to znamię w art. 12 k.k., jak również z charakterystyki instytucji czynu ciagłego. Znamię krótkich odstępów czasu umieszczone zostało w art. 12 k.k. w kontekście przesłanki podmiotowej w postaci „z góry powziętego zamiaru”. „Oba te elementy musza łącznie charakteryzować zachowania składające się na czyn ciagły. Czynnik podmiotowy w sposób istotny ogranicza więc możliwość wykładni znamienia "w krótkich odstępach czasu“”4. Autor ten podkreśla ponadto, że „[...] przepisy prawa, w tym przepisy prawa karnego, nie sa autonomiczne językowo, zaś prawidłowe odkodowanie ich normatywnego sensu wymaga uwzględnienia kontekstu całości tekstu prawnego, w jakim znajduje się interpretowana jednostka leksykalna. Kontekst obejmuje zarówno elementy ściśle językowe (tzw. kontekst wewnątrzzdaniowy i wokółzdaniowy), jak i kontekst instytucjonalny, obejmujacy także założony przez ustawodawcę cel danej instytucji prawnej"5.

Najogólniej rzecz ujmujac, wskazać należy, że na gruncie wykładni określenia „krótkie odstępy czasu” pojawiają się dwa zasadnicze problemy. Przede wszystkim kluczowa okazuje się odpowiedź na pytanie, czy krótkie odstępy czasu powinny wystapić pomiędzy kolejnymi, następującymi po sobie zachowaniami sprawcy, składającymi się na czyn ciąły, czy też krótki odstęp czasu wystapić ma pomiędzy zachowaniem pierwszym a ostatnim. Ponadto, co równie ważne, nie jest jasne, jaki odstęp czasu może zostać uznany za krótki. Analiza poglądów doktryny, a także orzecznictwa sądowego pozwala zauważyć, że na przedstawione powyżej pytania, udziela się rozmaitych odpowiedzi, które są w dużej mierze efektem subiektywnych odczuć i przekonań ich autorów. W niniejszym opracowaniu postaram się przytoczyć niektóre z tych poglądów.

W kwestii wątpliwości odnośnie tego, czy krótkie odstępy czasu maja zachodzić pomiędzy kolejnymi następujacymi po sobie zachowaniami czy też pomiędzy zachowaniem pierwszym a ostatnim, składającym się na czyn ciagły, wypowiedział się między innymi Kardas. Wyszedł on z założenia, że sformułowanie „w krótkich odstępach czasu” odnosi się do okresu występującego między kolejno następującymi po sobie zachowaniami. „[...] »krótkie odstępy czasu« to

\footnotetext{
2 III KK 276/16, Lex nr 2186061.

${ }^{3}$ Gardocki (2017): 158.

4 Kardas (2012): 209.

5 Kardas (2012): 209.
} 
odstępy między pierwszym, a drugim zachowaniem, drugim, a trzecim, trzecim, a czwartym itd. Artykuł 12 wymaga więc istnienia więzi czasowej między poszczególnymi, następującymi kolejno po sobie zachowaniami składajacymi się na czyn ciągły, nie zaś więzi zachodzącej między pierwszym a ostatnim zachowaniem wchodzącym w skład ciągu. Przepis art. 12 k.k. w żaden sposób nie określa natomiast granic trwania całego czynu ciagłego"6. Pogląd taki podziela także Małgorzata Dąbrowska-Kardas ${ }^{7}$. Z podobnego założenia wychodzi również Jacek Giezek ${ }^{8}$. Także Włodzimerz Wróbel oraz Andrzej Zoll uznaja, że krótkie odstępy czasu wystapić muszą pomiędzy kolejnymi następujacymi po sobie zachowaniami, a nie pomiędzy zachowaniem pierwszym a ostatnim ${ }^{9}$. Takie samo stanowisko zaprezentował również SN w wyroku z 26 marca 1999 r., przyjmując, że krótkie odstępy czasu wystapić muszą nie pomiędzy pierwszym, a ostatnim zachowaniem, składającym się na czyn ciagły, lecz pomiędzy kolejnymi następujacymi po sobie zachowaniami ${ }^{10}$. Sąd Najwyższy potwierdził to stanowisko między innymi w postanowieniu z 20 marca 2013 r. $^{11}$

Zupełnie odmienny pogląd w tej kwestii prezentuje natomiast Łukasz Pohl, stwierdzając, iż krótki odstęp czasu, o którym mowa w art. 12 k.k., powinien wystapić pomiędzy pierwszym a ostatnim zachowaniem składajacym się na ten czyn $^{12}$. Autor ten, zupełnie słusznie w moim przekonaniu, uznaje, że choć stanowisko, w myśl którego krótkie odstępy czasu powinny zachodzić pomiędzy kolejnymi następującymi po sobie zachowaniami, składajaccymi się na czyn ciagły, znajduje uzasadnienie w wykładni językowej rozważanego zwrotu, to jednak: „Z uwagi [...] na to, że prowadzi on do rezultatu społecznie niedorzecznego, należy go odrzucić, wszak bez wątpienia takim rezultatem jest uznanie za czyn ciagły kilkudziesięciu zgwałceń popełnianych przez sprawcę w krótkich odstępach czasu na krzywdę jego własnej małżonki (jest ono takim rezultatem ze względu na rozmiar grożącej temu sprawcy kary; [...] bowiem rozmiar ten wyznaczają granice kary grożącej przewidzianej dla popełnienia zachowania będącego składową czynu ciagłego). Słowem, wykładnia funkcjonalna nakazuje odstapić od rezultatu interpretacyjnego uzyskanego droga językowych reguł wykładni"13.

Pohl postuluje nowelizację art. $12 \mathrm{k} . \mathrm{k}$. i nadanie mu następującego brzmienia: „Dwa lub więcej zachowań, podjętych w krótkim odstępie czasu w wykonaniu z góry powziętego zamiaru, uważa się za ciagły czyn zabroniony; jeżeli przedmiotem zamachu jest dobro osobiste, warunkiem uznania wielości zachowań za ciagły czyn zabroniony jest tożsamość pokrzywdzonego" ${ }^{14}$. Zdaniem tego autora „[...] należałoby już w samej warstwie deskryptywnej art. 12 k.k.

\footnotetext{
${ }^{6}$ Kardas (2012): 211.

7 Dąbrowska-Kardas (1999): 45-46.

8 Giezek (2017): 309-310.

9 Wróbel, Zoll (2014): 294.

10 IV KKN 28/99, Lex nr 37938.

11 III KK 409/12, Legalis nr 662869.

12 Pohl (2019): 268.

13 Pohl (2017): 200.

14 Pohl (2019): 108.
} 
jednoznacznie przesądzić, że wszystkie zachowania składające się na czyn ciagły muszą być popełnione w krótkim odstępie czasu. Sformułowana wyżej propozycja zmiany art. 12 k.k., przechodząc z formuły "krótkich odstępów czasu" na formułę "krótkiego odstępu czasu«, rzecz tę w taki właśnie sposób rozstrzyga"15. Pogląd, w myśl którego krótki odstęp czasu powinien wystapić pomiędzy pierwszym a ostatnim zachowaniem składającym się na czyn ciagły, wydaje się słuszny. Gdyby było tak, że krótki odstęp czasu, o którym mowa w art. 12 $\S 1$ k.k., ma wystapić jedynie pomiędzy kolejnymi zachowaniami statuującymi czyn ciagły, tj. pomiędzy zachowaniem pierwszym a drugim, drugim a trzecim itd., mogłoby zdarzyć się tak (i najpewniej by się zdarzyło), że odstęp pomiędzy pierwszym a ostatnim zachowaniem byłby na tyle długi, że uznanie, iż w danej sprawie mamy do czynienia z czynem ciagłym, niejako wypaczałoby ideę tej instytucji, albowiem prowadziłoby do traktowania jako czyn ciagły zachowań, spośród których zachowanie pierwsze i ostatnie są od siebie bardzo mocno oddalone w czasie.

Jak była o tym już wcześniej mowa, również odpowiedź na pytanie, jaki okres można uznać za mieszczący się w krótkich odstępach czasu, wywołuje wiele rozbieżności nie tylko wśród przedstawicieli doktryny, ale także w orzecznictwie sądowym. W piśmiennictwie karnistycznym spotkać można się niekiedy z opinia, że przy ustalaniu, jakie odstępy czasu można określić mianem krótkich, należy odwołać się do definicji legalnej zawartej w art. 6 § 2 ustawy z 10 września 1999 r. - Kodeks karny skarbowy, a ściślej do następującego fragmentu tego przepisu: „[...] w zakresie czynów zabronionych polegających na uszczupleniu lub narażeniu na uszczuplenie należności publicznoprawnej za krótki odstęp czasu uważa się okres do 6 miesięcy". Pogląd taki prezentuje między innymi Marek Kulik, który twierdzi, że takie rozumienie tego pojęcia wydaje się dopuszczalne również na gruncie Kodeksu karnego. Brak bowiem, jego zdaniem, argumentów przemawiających za tym, aby identyczne pojęcia, użyte w dwóch pokrewnych aktach prawnych, wykładane były odmiennie ${ }^{16}$. Takie stanowisko zaprezentował także SN w wyroku z 9 marca 2006 r., uznając, że choć uregulowanie przyjęte w art. $6 \S 2$ k.k.s. dotyczy przestępstw godzaccych w interesy finansowe Skarbu Państwa, to jednak można uważać je za wskazówkę ustawodawcy co do sposobu rozumienia terminu „krótki odstęp czasu" użytego również w innych ustawach, a w tym także w Kodeksie karnym ${ }^{17}$.

Słuszne wydaje się jednak stanowisko Pohla, że definicji krótkich odstępów czasu zawartej w art. $6 \S 2$ k.k.s. nie można automatycznie przenosić na grunt art. 12 k.k., albowiem dotyczy ona jedynie wybranego, wskazanego $\mathrm{w}$ art. $6 \S 2$ k.k.s. fragmentarycznego obszaru deliktów karnoskarbowych ${ }^{18}$. Pogląd zaprezentowany przez Łukasza Pohla podziela także Tadeusz Bojarski, uznając, że czyny, o których mowa w art. $6 \S 2$ k.k.s., mają szczególny

\footnotetext{
15 Pohl (2019): 110.

16 Kulik (2012): 44.

17 V KK 271/05, Legalis nr 74495.

18 Pohl (2019): 269.
} 
charakter, albowiem odnoszą się one do stosunków finansowych, zwłaszcza podatkowych $^{19}$.

Również Kardas wskazuje, że wprowadzenie definicji krótkich odstępów czasu do k.k.s. traktować należy nie jako pewnego rodzaju wskazówkę interpretacyjna, dotyczącą sposobu dokonywania wykładni zwrotu „krótkie odstępy czasu" na gruncie innych ustaw, w tym w szczególności art. 12 k.k., lecz wyłącznie jako rozwiązanie wyjątkowe. „Nie tracąc z pola widzenia, że wprowadzając regulację wskazująca na szerokie rozumienie przesłanki czasowej czynu ciagłego na gruncie k.k.s., ustawodawca istotnie zmodyfikował zarówno przesłankę subiektywna, jak i poszerzył instytucję czynu ciagłego na wypadki powiązane wyłącznie elementami obiektywnymi, stwierdzić należy, że z regulacji art. 6 § 2 k.k.s. odczytać można wskazanie na wąską wykładnię zwrotu "w krótkich odstępach czasu" na gruncie art. 12 k.k." ${ }^{20}$.

W kwestii pojęcia „w krótkich odstępach czasu” Giezek stoi na stanowisku, że trudno byłoby zaakceptować stwierdzenie, w myśl którego krótkie odstępy czasu, które w identycznym kształcie pojawiły się w art. 12 k.k. oraz w dotyczacym ciagu przestępstw art. 91 k.k., interpretować można na potrzeby każdego z tych przepisów w różny sposób, albowiem byłoby to sprzeczne z wykładnią językową. Zgodnie z podstawową regułą wykładni ten sam zwrot użyty $\mathrm{w}$ ustawie rozumieć trzeba przecież jednolicie ${ }^{21}$.

Chronologiczny przegląd orzecznictwa SN w kwestii interpretacji pojęcia krótkich odstępów czasu, a ściślej w kwestii doprecyzowania, jakie odstępy czasu uznać można za krótkie - prowadzi do wniosku, że SN w kolejnych orzeczeniach zaprezentował poglądy wzajemnie sobie w tym zakresie przeczace. W wyroku Izby Karnej SN z 12 kwietnia 1975 r., sformułowany został pogląd, że odstępy pomiędzy kolejnymi zachowaniami wynoszące półtora roku umożliwiaja przyjęcie czynu ciagłego, a co za tym idzie, stanowią one krótkie odstępy czasu, „[...] skoro kontynuacja zamiaru przestępnego wynikała z jego [oskarżonego - P.B.] każdorazowej bezspornej gotowości do włączania się w przestępny proceder, a okresy przerwy podyktowane zostały jedynie brakiem nadarzającej się okazji" "22. W uchwale Izby Karnej SN z 11 marca 1988 r. mowa jest o tym, że aby w danej sytuacji było możliwe przyjęcie czynu ciagłego, pomiędzy kolejnymi podjętymi przez sprawcę zachowaniami muszą wystąpić stosunkowo krótkie odstępy czasu $^{23}$. Nie sposób nie zauważyć, że określenie „stosunkowo krótkie odstępy czasu” tak naprawdę niewiele wyjaśnia, a już z całą pewnością nie konkretyzuje, jaki okres można uznać za mieszczący się w krótkich odstępach czasu.

W wyroku z 26 marca 1999 r. SN zwrócił uwagę na to, że „[...] przymiotnik "krótki« ma charakter relatywny. Określa on bowiem czas trwania jakiegoś zdarzenia w relacji do typowej, zwykłej długości trwania takich zdarzeń. Zgodzić się wypada z treścią poglądów doktryny, że zwrot "w krótkich odstępach

\footnotetext{
19 Bojarski (2013): 71.

${ }^{20}$ Kardas (2012): 214.

21 Giezek (2017): 310.

22 V KR 130/74, Legalis nr 18702.

${ }^{23}$ VI KZP 49/87, Legalis nr 26191.
} 
czasu“ rozumieć należy jako przedział czasowy wynoszący nie więcej niż kilkanaście dni, a także z teza, że w przypadku przekroczenia odstępu kilkunastu dni między jednym a drugim zachowaniem - nawet wówczas, gdy sprawca miał z góry powzięty zamiar popełnienia większej ilości - wykluczone jest przyjęcie czynu ciagłego"24.

Odmienny pogląd SN został natomiast zaprezentowany w wyroku z 5 kwietnia 2000 r., w którym Sąd ten staną na stanowisku, że miesięczna rozpiętość czasu pomiędzy pierwszym a drugim czynem, w sytuacji gdy kolejnych czynów sprawca dopuszczał się co kilka dni (niekiedy nawet co drugi dzień) lub też co kilkanaście dni, nie stoi na przeszkodzie ustaleniu, iż działał on właśnie w krótkich odstępach czasu ${ }^{25}$. Są Najwyższy dopuścił zatem $\mathrm{w}$ tym wyroku szerszą interpretację analizowanego pojęcia, aniżeli w wyroku z 26 marca 1999 r., zakładając, że za krótki odstęp czasu można uznać także odstęp miesięczny pomiędzy dwoma następującymi po sobie zachowaniami ${ }^{26}$. Postanowienie SN z 18 września 2003 r. nawiązuje natomiast do pojęcia krótkich odstępów czasu zdefiniowanego w wyroku z 26 marca 1999 r., przez przyjęcie, że „krótkie odstępy czasu to przedział obejmujący najwyżej kilkanaście dni” i tym samym ponownie zawęża zakres czasowy, który można interpretować jako krótki odstęp czasu ${ }^{27}$.

$\mathrm{Na}$ uwagę zasługuje również fakt, że w wyroku z 1 lutego $2006 \mathrm{r}$. SN po raz kolejny zaprezentował skrajnie odmienny od poprzednich pogląd, w myśl którego krótkimi odstępami czasu są odstępy pomiędzy kolejnymi zachowaniami wynoszące nie tylko od jednego do kilku dni, ale także wynoszące niemal półtora miesiąca ${ }^{28}$. W postanowieniu Izby Karnej SN z 9 marca 2006 r., wydanym nieco ponad miesiąc po wyroku z 1 lutego 2006 r., uznano z kolei, zupełnie odmiennie niż poprzednio, że nawet kilkumiesięczne odstępy czasowe występujace pomiędzy kolejnymi zachowaniami sprawcy czynu ciagłego, mogą być w pewnych okolicznościach traktowane jako „krótkie odstępy czasu” w rozumieniu art. $12 \mathrm{k} . \mathrm{k} \cdot{ }^{29}$

W postanowieniu Izby Karnej SN z 4 marca 2008 r. mowa jest natomiast o tym, że okres pomiędzy dwoma kolejnymi zrealizowanymi przez sprawcę zachowaniami przekraczający dwa lata nie może być uznany za „krótki odstęp czasu" w rozumieniu art. 12 k.k. ${ }^{30}$ Z kolei w wyroku z 29 września 2010 r. SN doszedł do wniosku, że: „Przyjęcie kilkuletniego okresu działania skazanego ze z góry powziętym zamiarem jest możliwe, jednakże pod warunkiem krótkich, maksymalnie kilkumiesięcznych odstępów czasowych pomiędzy poszczególnymi aktami sprawczymi, pozwalajacymi na wykazanie "z góry powziętego zamiaru«, zrealizowanego wobec wszystkich zindywidualizowanych,

\footnotetext{
${ }^{24}$ IV KKN 28/99, Lex nr 37938.

25 V KKN 41/00, Lex nr 50957.

${ }_{26}$ IV KKN 28/99, Lex nr 37938.

${ }^{27}$ III KK 159/02, Lex nr 81203.

28 II KK 127/05, Legalis nr 75278.

29 V KK 271/05, Legalis nr 74495.

30 III KK 302/07, Lex nr 361537.
} 
choćby w ogólnym zarysie zamierzonych zachowań" ${ }^{31}$. Za takim rozumieniem pojęcia „krótkie odstępy czasu” opowiada się także Kulik ${ }^{32}$. Również w wyroku z 8 stycznia 2014 r. SN przyjął, że krótkie odstępy czasu to odstępy nieprzekraczające kilku miesięcy ${ }^{33}$.

Warto w tym miejscu przytoczyć również pogląd Sądu Apelacyjnego w Krakowie wyrażony w wyroku z 10 maja 2000 r., zgodnie z którym z czynem ciagłym nie mamy do czynienia wtedy, gdy sprawca działał w odstępach czasu „przekraczających rozsądne granice jedności zachowania”34, jak również wyrok SA w Katowicach z 22 listopada 2001 r., z którego wynika, że okres kilkunastu dni pomiędzy poszczególnymi przestępczymi zachowaniami w pełni realizuje przesłankę krótkich odstępów czasu, o której mowa w przepisie art. 12 k.k., i umożliwia przyjęcie działania przez sprawcę w warunkach czynu ciągłego, wynikającego z tego przepisu - co oczywiste, tylko pod warunkiem realizacji pozostałych okoliczności w nim wymienionych"35. Rozstrzygnięcie to wyraźnie nawiązuje do wyroku SN z 26 marca 1999 r. ${ }^{36}$ oraz do postanowienia SN z 18 września 2003 r. ${ }^{37}$, o których była już wcześniej mowa. Sąd Apelacyjny w Krakowie w wyroku z 9 października 2007 r. stwierdził natomiast, że nie można przyjąć, że mamy do czynienia z krótkimi odstępami czasu, jeśli przerwy między kolejnymi zachowaniami dochodzą do kilku miesięcy ${ }^{38}$.

Zdaniem Pohla, pojawiające się na gruncie pojęcia krótkich odstępów czasu rozbieżności, powinny być usunięte wprowadzeniem do Kodeksu karnego definicji legalnej tego pojęcia. Autor ten wskazuje bowiem, że: „Nie może być przecież tak, że przy takich samych odstępach czasu pomiędzy zachowaniami się sprawcy jeden podmiot stosujacy prawo - na skutek żywionych w tym zakresie intuicji - uzna, że sa one krótkie, a drugi, żywiąc w tym zakresie intuicje odmienne, stwierdzi, że krótkimi one nie są (tego rodzaju układ jest bowiem jawnym pogwałceniem zasady równego traktowania jednostek wobec prawa)"39. Pohl stoi na stanowisku, że krótki odstęp czasu, o którym mowa w art. 12 k.k., nie powinien przekraczać 31 dni, podkreślając przy tym, że opinia ta wynika z jego subiektywnych przekonań i tym samym jest ona opinią arbitralna ${ }^{40}$. Przywołany autor proponuje dodanie do art. 115 k.k. $§ 25$, którego brzmienie byłoby następujące: „Krótki odstęp czasu to okres nieprzekraczający 31 dni" ${ }^{41}$.

Bojarski wychodzi natomiast z założenia, że w przypadku krótkich odstępów czasu na gruncie czynu ciąłego nie jest możliwe wskazanie konkretnej liczby dni ani też miesięcy dzielących poszczególne zachowania sprawcy, któ-

\footnotetext{
${ }^{31}$ III KK 60/10, Lex nr 621185.

${ }^{32}$ Kulik (2012): 44.

${ }^{33}$ IV KK 255/13, Legalis nr 787050.

34 II AKa 69/00, Lex nr 42938.

${ }^{35}$ II AKa 400/ 01, Lex nr 56726.

36 IV KKN 28/99, Lex nr 37938.

37 III KK 159/02, Lex nr 81203.

38 II AKa 164/07, Legalis nr 95465.

39 Pohl (2017): 199.

40 Pohl (2019): 269.

41 Pohl (2019): 108.
} 
rych upływ pozwoliłby na przyjęcie, iż na gruncie konkretnego stanu faktycznego mamy do czynienia z czynem ciagłym. „Wydaje się, że trzeba tu sięgnąc do ocen społecznych - z tego punktu widzenia będą to odstępy czasowe w rozmiarze kilku dni, tygodni i raczej nie dłuższe niż kwartał roku" 42 .

Za wąskim sposobem rozumienia przesłanki krótkich odstępów czasu opowiada się także Kardas. Autor ten wskazuje bowiem, że: „[...] nie uzasadnia przyjęcia szerokiego rozumienia granic czasowych czynu ciagłego w sposób umożliwiający przyjęcie tej konstrukcji w sytuacji, gdy pomiędzy poszczególnymi zachowaniami występują odstępy kilkumiesięczne to, że taki okres czasu nie wyklucza możliwości przyjęcia, iż sprawca realizował poszczególne zachowania "w wykonaniu z góry powziętego zamiaru". [...] Wystapienie przesłanki subiektywnej stanowi warunek konieczny czynu ciagłego, nie jest jednak warunkiem wystarczającym. Ustawodawca, wprowadzając kryterium krótkich odstępów czasu do konstrukcji czynu ciagłego, zmierzał niewątpliwie do zawężenia zakresu zastosowania tej instytucji, w sposób odpowiadajacy podstawowemu celowi regulacji zawartej w art. 12 k.k., tj. stworzeniu podstaw łącznej oceny dwóch lub więcej zachowań realizowanych niejako "na raty", a więc pozostających w takich związkach, także czasowych, które nie przekraczaja rozsądnych granic jedności całości zachowania"43.

Kardas wychodzi również z założenia, że szeroka wykładnia czynu ciagłego może prowadzić do naruszenia ratio legis tej instytucji, a także stanowić podstawę do komplikacji związanych z praktycznym jej wykorzystywaniem. „[...] niezależnie od niezbyt precyzyjnej wypowiedzi ustawodawcy, warunek czasowy czynu ciagłego wykładać należy w sposób umożliwiający objęcie ramami tej instytucji tylko takich zachowań, które charakteryzują się więziami umożliwiającymi uznanie ich za fragment większej całości. Konieczne związki pomiędzy poszczególnymi zachowaniami wyraźnie podkreśla ustawodawca, wskazując na warunek subiektywny w postaci z góry powziętego zamiaru. W tym też sensie wydaje się, że przesłanka »krótkich odstępów czasu« interpretowana z uwzględnieniem sensu i celu instytucji, którą charakteryzuje, powinna być interpretowana ścieśniająco" ${ }^{44}$.

Autor ten dodaje ponadto, że szeroka wykładnia instytucji czynu ciagłego rodzi bardzo poważne trudności na płaszczyźnie wymiaru kary. Jest tak dlatego, że art. $12 \mathrm{k} . k$. nie przewiduje możliwości nadzwyczajnego jej obostrzenia. W przypadku szerokiego rozumienia pojęcia „krótkich odstępów czasu” między poszczególnymi zachowaniami stanowi ona, zdaniem tego autora, podstawę do twierdzenia, że przyjęcie czynu ciąłego działa na korzyść sprawcy. Waska interpretacja takich komplikacji na płaszczyźnie wymiaru kary nie wywołuje ${ }^{45}$. Dlatego też Kardas prezentuje pogląd, że: „Uwzględniając charakter czynu ciągłego, prowadzącego do przyjęcia jednego czynu zabronionego, kontekst, w jakim najczęściej występuje zwrot "w krótkich odstępach czasu«, znamię

\footnotetext{
42 Bojarski (2013): 71.

43 Kardas (2012): 211-212.

${ }^{44}$ Kardas (2012): 214.

45 Kardas (2012): 214-215.
} 
podmiotowe czynu ciągłego w postaci »z góry powziętego zamiaru oraz prawnokarne konsekwencje wynikające z przyjęcia tej koncepcji prawnej można przyjąć, że krótkie odstępy czasu to okres trwający od kilku minut do maksimum kilku lub kilkunastu dni" ${ }^{46}$.

Pogląd ten podzielają także Wróbel oraz Zoll ${ }^{47}$. Podobnie Jarosław Warylewski przyjmuje, że krótkie odstępy czasu to odstępy kilkudniowe lub kilkunastodniowe ${ }^{48}$. Autor ten podkreśla jednak, że w wyjątkowych przypadkach należy dopuścić przerwy dłuższe - nawet kilkumiesięczne -między poszczególnymi zachowaniami ${ }^{49}$. Mirosław Surkont nie precyzuje, jaki odstęp czasu można uznać za krótki. Wskazuje jedynie, że należy zakładać, że dłuższa przerwa między zachowaniami sprawcy uniemożliwia potraktowanie ich jako czynu ciagłego ${ }^{50}$.

Kardas podkreśla, że przyjęcie, iż zwrot „w krótkich odstępach czasu” rozumieć należy jako okres wynoszący nie więcej niż kilkanaście dni, nie oznacza wcale, że cały czyn ciagły rozciagać się musi jedynie na przestrzeni kilkunastu dni. Odstęp czasowy wynoszący nie więcej niż kilkanaście dni musi być bowiem zachowany jedynie między poszczególnymi zachowaniami składającymi się na ciąg zachowań. Jeśli pomiędzy kolejno następującymi po sobie zachowaniami występować będą krótkie odstępy czasu, to odległość między pierwszym a ostatnim zachowaniem składającym się na czyn ciąłły wynosić może nawet rok. Przyjęcie w takim wypadku czynu ciagłego nie naruszy przesłanki podjęcia zachowań w krótkich odstępach czasu, między poszczególnymi zachowaniami realizowanymi kolejno przesłanka ta bowiem będzie zachowana, a to przecież tylko ten przedział czasowy ma, zdaniem tego autora, znaczenie z punku widzenia znamion instytucji określonej w art. 12. k.k. ${ }^{51}$

Giezek w swoim dość obszernym wywodzie, który w tym miejscu przytoczony zostanie in extenso, wyraża obawę, że: „[...] tak znaczna dowolność interpretacyjna nadmiernie zrelatywizuje omawianą przesłankę, czyniąc z niej kryterium mało użyteczne. Okazuje się bowiem, że odstępy czasu nie są same w sobie krótkie lub długie, lecz stają się takie względem jakiegoś niezbyt wyraźnie określonego układu odniesienia. W pewnym sensie niepokoić także może stwierdzenie, że konieczne jest dopiero wypracowanie kryteriów zbieżności czasowej, o której mowa w art. 12 k.k., co - zdaniem niektórych autorów - pozostawić należy orzecznictwu sądowemu. Jeśli bowiem miałoby to oznaczać, że pozaustawowe kryteria ostatecznie zadecydują o tym, że jakiśs odstęp czasowy w jednym wypadku oceniony zostanie jako krótki, w innym zaś ocena ta wypadnie zupełnie inaczej, to w rezultacie prowadzić to może do wniosku, iż owe kryteria staną się - niezależnie od relacji czasowej między poszczególnymi zachowaniami - samodzielną pozaustawowa przesłanką ciagłości przestępstwa. Ważne będzie wówczas nie to, czy odstęp czasu w istocie

\footnotetext{
${ }^{46}$ Kardas (2012): 210.

47 Wróbel, Zoll (2014): 294.

48 Warylewski (2017): 482.

49 Warylewski (2017): 482.

50 Surkont (2001): 134.

51 Kardas (2012): 211.
} 
jest krótki (co z łatwością można wszak aż do absurdu zrelatywizować), lecz czy oceniono go jako krótki. Istotniejsza okaże się więc sama ocena niż jej przedmiot" ${ }^{\prime 2}$.

Przyjęcie, że krótki odstęp czasu to odstęp nieprzekraczający kilku czy też kilkunastu dni jest, w moim przekonaniu, nadmiernym zawężeniem analizowanej kwestii. Z uwagi na to, że - jak już wcześniej starałam się wykazać - krótki odstęp czasu powinien wystapić pomiędzy pierwszym a ostatnim zachowaniem składającym się na czyn ciąły, a nie pomiędzy kolejnymi zachowaniami, które się na czyn ciagły składaja, uznać należy, że odstęp ten może trwać nieco dłużej niż kilka czy też kilkanaście dni. Przy przyjęciu takiego założenia, nawet jeśli pomiędzy kolejnymi zachowaniami składającymi się na czyn ciagły wystapią odstępy trwające kilkanaście dni, będzie można uznać, że w danej sytuacji mamy do czynienia z czynem ciagłym pod warunkiem, że pomiędzy pierwszym a ostatnim zachowaniem upłyną maksymalnie miesiąc. Przyjęcie, że pomiędzy pierwszym a ostatnim zachowaniem składającym się na czyn ciagły może upłynąć nie więcej czasu niż miesiąc, wynika z czysto subiektywnego przekonania, iż okresu dłuższego niż miesiąc nie sposób uznać za krótki. Zgodnie bowiem ze słownikiem pod redakcją Witolda Doroszewskiego, słowo „krótki” znaczy tyle, co 1. „mający małą długość, niedługi”, 2. „trwający niedługi okres czasu, krótkotrwały”33.

Przyjęcie, że krótki odstęp czasu, o którym mowa w art. $12 \S 1$ k.k., to nie dłużej niż miesiąc, pozwala jednocześnie na uniknięcie sytuacji, w której to dojdzie do nadmiernego relatywizowania tego pojęcia i tym samym do zbyt szerokiego jego rozumienia, a w konsekwencji do przyjmowania, że mamy do czynienia z czynem ciagłym w sytuacjach, w których pomiędzy pierwszym a ostatnim zachowaniem składającym się na ten czyn upłynie czas, którego z całą pewnością obiektywnie nie będzie można uznać za krótki. Mianem krótkiego odstępu czasu bez wątpienia nie można nazwać odstępu wynoszącego kilka miesięcy, rok, a tym bardziej dwa lata.

W sytuacji natomiast, gdy sprawca dopuści się kilku zachowań w wykonaniu z góry powziętego zamiaru, a ostatnie z tych zachowań zostanie zrealizowane po upływie miesiąca od zachowania pierwszego, nie należy wówczas w ogóle zrezygnować z zastosowania konstrukcji czynu ciagłego. Wystarczające jest bowiem wyeliminowanie z niej ostatniego z objętych zamiarem zachowań i uznanie, że czyn ciagły miał miejsce jedynie w odniesieniu do pozostałych zrealizowanych wcześniej zachowań. Podkreślenia wymaga, że jako pierwsze zachowanie, które składa się na czyn ciagły będzie traktowane to zachowanie, które zrealizowane zostało najwcześniej. Jeśli zatem sprawca dopuszcza się na przykład czterech zachowań w wykonaniu z góry powziętego zamiaru, a jedynie zachowanie pierwsze, drugie oraz trzecie zawiera się $w$ granicach miesiąca, a zachowanie czwarte zostało podjęte już po upływie miesiąca od zachowania pierwszego, to tylko trzy pierwsze zachowania będą się składały na czyn ciagły, zachowanie czwarte zaś - to, które podjęte zostało już po upływie

\footnotetext{
52 Giezek (2017): 309.

${ }^{53}$ Zob. <https://sjp.pwn.pl/doroszewski/krotki;5443940.html> [dostęp: 1.10.2019].
} 
miesiąca od momentu, w którym zrealizowane zostało pierwsze z zachowań, będzie rozpatrywane osobno - nie w ramach czynu ciagłego, ale jako odrębny czyn. Należy mieć na uwadze, że w obecnie obowiązujacym stanie prawnym przyjęcie na gruncie konkretnej sytuacji konstrukcji czynu ciagłego nie pociąga za sobą możliwości obostrzenia kary, jaka może zostać wymierzona sprawcy, który dopuścił się czynu w warunkach, o których mowa w art. 12 § k.k. Kara, jaką można wymierzyć sprawcy dopuszczającemu się czynu zabronionego w warunkach czynu ciagłego, jest bowiem tożsama z kara przewidziana za poszczególne czyny składające się na czyn ciagły. Można zatem pokusić się o stwierdzenie, że potraktowanie kilku zachowań sprawcy jako czyn ciagły jest w wielu sytuacjach rozwiązaniem działającym na jego korzyść. Z tego chociażby względu nie należałoby w moim przekonaniu nadmiernie rozszerzać sposobu rozumienia pojęcia „krótkie odstępy czasu”.

Warto w tym kontekście wspomnieć, iż w ustawie z 13 czerwca 2019 r. o zmianie ustawy Kodeks karny oraz niektórych innych ustaw zaproponowano między innymi dodanie do kodeksu art. 57b, który miałby brzmieć w sposób następujacy: „Skazując za przestępstwo określone w art. $12 \S 1$ sąd wymierza karę przewidziana za przypisane sprawcy przestępstwo w wysokości od dolnej granicy zagrożenia zwiększonego o połowę do podwójnej wysokości górnej granicy ustawowego zagrożenia" 54 . Uchwalona ustawa nie weszła jednak w życie. Została ona skierowana do Trybunału Konstytucyjnego celem zbadania jej zgodności z Konstytucja. Pomimo przedstawionych powyżej problemów i kontrowersji, które pojawiają się podczas analizy przedmiotowego zagadnienia, stwierdzić w moim przekonaniu należy, że wprowadzenie do Kodeksu karnego definicji legalnej krótkich odstępów czasu nie byłoby właściwym rozwiązaniem. Jedynie z pozoru mogłoby się wydawać, że definicja ta rozwiałaby wszelkie wątpliwości, które w tej kwestii mogą się pojawić. Należy mieć jednak na uwadze fakt, że wprowadzenie takiej definicji byłoby w istocie rzeczy rozwiązaniem sztucznym, które w pewien sposób wypaczałoby istotę instytucji czynu ciagłego. Oczywiste jest, że instytucja ta powinna być stosowana tylko wtedy, kiedy jest to uzasadnione, a co za tym idzie, przede wszystkim wtedy, gdy odstępy czasu pomiędzy pierwszym a ostatnim zachowaniem podjętym przez sprawcę są rzeczywiście krótkie, jednakże samego pojęcia „krótkich odstępów czasu" nie należy precyzować wprowadzaniem do Kodeksu karnego jego definicji legalnej.

Przedstawiona w niniejszym artykule analiza sposobu rozumienia użytego przez ustawodawcę w art. 12 k.k. pojęcia „krótkie odstępy czasu” nie jest z cała pewnościa analizą całościowo tę problematykę charakteryzująca. Celem artykułu jest bowiem wskazanie najważniejszych problemów, jakie pojawiaja się na gruncie wykładni analizowanego pojęcia, a także przedstawienie sposobu jego rozumienia przez przedstawicieli nauki prawa karnego oraz przez wybrane sądy, w szczególności przez SN. Podsumowując powyższe rozważania, należy stwierdzić, że termin „krótkie odstępy czasu” z uwagi na brak definicji

${ }_{54}$ Zob.<http://orka.sejm.gov.pl/Druki8ka.nsf/0/996CE307123D03FEC12583FA0069E8F2/\%24File/3451.pdf> [dostęp: 1.10.2019]. 
kodeksowej rodzi zarówno w doktrynie prawa karnego, jak i w orzecznictwie liczne wątpliwości na gruncie wykładni, co znajduje wyraz chociażby w tym, że sam SN na przestrzeni kolejnych lat w sposób różnoraki je interpretował. Pomimo jednak tak licznych wątpliwości, które rodzą się na gruncie przedmiotowego pojęcia, nie jest zasadne precyzowanie go przez wprowadzanie do Kodeksu karnego jego definicji legalnej.

Paulina Banaszak-Grzechowiak

Uniwersytet Szczecinski

paulina.banaszak@iws.gov.pl

https://orcid.org/0000-0002-7367-0860

Bojarski, T. (2013). [Komentarz do art. 12 kodeksu karnego], [w:] T. Bojarski (red.), Kodeks karny. Komentarz. Warszawa: 71.

Dąbrowska-Kardas, M. (1999). Komentarz do art. 12 i 91 Kodeksu karnego. [w:] M. Dąbrowska-Kardas, P. Kardas, Czyn ciąły i ciąg przestępstw. Kraków.

Gardocki, L. (2017). Prawo karne. Warszawa.

Giezek, J. (2017). [Zbieg przepisów ustawy oraz zbieg przestępstw], [w:] M. Bojarski (red.), Prawo karne materialne. Część ogólna i szczególna. Warszawa: 309-310.

Kardas, P. (2012). [Komentarz do art. 12 Kodeksu karnego], [w:] A. Zoll (red.), Kodeks karny. Część ogólna. Komentarz Lex. Warszawa.

Kulik, M. (2012). [Komentarz do art. 12 Kodeksu karnego], [w:] M. Mozgawa (red.), Kodeks karny. Komentarz. Warszawa.

Namysłowska-Gabrysiak, B. (2017). Prawo karne - część ogólna. Warszawa.

Pohl, Ł. (2017). [Komentarz do art. 12 Kodeksu karnego], [w:] R.A. Stefański (red.), Kodeks karny. Komentarz. Warszawa.

Pohl, Ł. (2019). Prawo karne. Wykład części ogólnej. Warszawa.

Surkont, M. (2001). Prawo karne. Gdynia.

Warylewski, J. (2017). Prawo karne. Część ogólna. Warszawa.

Wróbel, W., Zoll, A. (2014). Polskie prawo karne. Część ogólna. Kraków.

Zientara, A. (2014). Prawo karne materialne. Warszawa.

\section{SHORT INTERVALS OF TIME \\ AS A CONDITION OF A CONTINUOUS ACT}

\section{Sum mary}

The concept of a continuous act is regulated in Article 12 of the Act of 6 June 1997 - Penal Code. This provision indicates the conditions that must be met in order for a continuous act to occur. One of these conditions is short intervals of time. The Penal Code lacks a legal definition of this concept, which entails numerous disputes and controversies as to how it should be understood. Some of the doubts raised by the representatives of the doctrine are presented in this article. They concern, among other issues, whether short intervals of time should occur between the first and last acts of conduct constituting a continuous act, or between successive acts of conduct, and how long a period of time must be to be considered as a short interval of time. The author also presents her own position on the most important issues related to the discussed issues.

Keywords: continuous act; short intervals of time 